\title{
Tuberous Sclerosis as a cause of difficult-to-control Epilepsy - Case report
}

\section{Walter Leonardo Alves Gusmão ${ }^{1 *}$, Antonio Marcos da Silva Catharino², Gilberto Canedo M. Jr³, Tatiane Daniele de Almeida Costa ${ }^{4}$, Nicolle dos Santos Moraes Nunes ${ }^{5}$, Jacqueline Stephanie Fernandes do Nascimento ${ }^{6}$, Janie Kelly Fernandes do Nascimento ${ }^{7}$, Marco Antônio Orsini Neves ${ }^{8}$.}

\section{${ }^{1}$ Resident Physician of Medical Clinic of the General Hospital of Nova Iguaçu (HGNI).}

${ }^{2}$ Neurologist at HGNI, Master Degree in neurology at HUGG / UNIRIO, Professor of the Medical School of UNIG, Nova Iguaçu / RJ.

${ }^{3}$ Neurologist at HGNI, Professor of the Medical School of UNIG, Nova Iguaçu/RJ. ${ }^{4}$ Physician at HGNI, Professor of the Medical School of UNIG, Nova Iguaçu/RJ.

${ }^{5}$ Medical Student at UNIG, Nova Iguaçu/RJ.

${ }^{6}$ Medical Student at UNIG, Nova Iguaçu/RJ.

${ }^{7}$ Medical Student at UNIG, Nova Iguaçu/RJ.

${ }^{8}$ Neurologist, Professor of the Medical School of UNIG, Nova Iguaçu/RJ.
Address for correspondence: Walter Leonardo Alves Gusmão. Rua São Clemente, 262 APT 103 BL 2 Botafogo, CEP 22260-004, Rio de Janeiro/RJ, Brasil.

E-mail: walterleo05@yahoo.com.br

How to cite this article: Gusmão WLA, Catharino AMS, Gilberto CMJ, Costa TDA, Nunes NSM, et al. Tuberous Sclerosis as a cause of difficult-to-control Epilepsy - Case report. G Med Sci. 2020; 1(5): 073-077.

https://www.doi.org/10.46766/thegms.neuro.20102304

Copyright: @ 2020 Walter Leonardo Alves Gusmão, Antonio Marcos da Silva Catharino, Gilberto Canedo M. Jr, Tatiane Daniele de Almeida Costa, Nicolle dos Santos Moraes Nunes, Jacqueline Stephanie Fernandes do Nascimento, Janie Kelly Fernandes do Nascimento, Marco Antônio Orsini Neves. This is an Open Access article distributed under the Creative Commons Attribution License, which permits unrestricted use, distribution, and reproduction in any medium, provided the original work is properly cited.

*This study was carried out at the Neurology Outpatient Clinic of the General Hospital of Nova Iguaçu, Nova Iguaçu / RJ, Brazil.

Estudo realizado no Ambulatório de Neurologia do Hospital Geral de Nova Iguaçu, Nova Iguaçu/RJ, Brasil.

\section{Abstract/ Resumo}

Tuberous Sclerosis Complex or Bourneville's disease is an autosomal dominant disease with high penetrance and variability characterized by multisystem involvement by benign lesions, originally defined by the classic triad of Vogt: sebaceous adenoma, epilepsy and mental retardation. The involvement of the brain is responsible for a significant proportion of the morbidity and mortality of this disease and skin lesions are the most common manifestations. The authors report 31-year-old patient case referred to the service by intractable epilepsy with definitive clinical criteria for tuberous sclerosis.

Keywords: tuberous sclerosis, epilepsy, angiofibroma.

O complexo esclerose tuberosa ou doença de Bourneville é uma doença autossômica dominante com elevadas penetrância e variabilidade caracterizada pelo acometimento multissistêmico por lesões benignas, sendo originalmente definida pela tríade clássica de Vogt: adenoma sebáceo, epilepsia e atraso mental. $O$ envolvimento do cérebro é responsável por uma proporção significativa da morbidade e mortalidade dessa enfermidade e as lesões cutâneas são as manifestações mais comuns. Os autores relatam caso de paciente de 31 anos encaminhado ao serviço por epilepsia de difícil controle com critérios clínicos definitivos para esclerose tuberosa.

Palavras-chave: esclerose tuberosa, epilepsia, angiofibroma. 


\section{Introduction}

The tuberous Sclerosis Complex (TSC) is a neurocutaneous, hereditary, autosomal dominant syndrome, first described in 1880 by Bourneville. Santalha is characterized by the growth of hamartomas in multiple organs such as skin, nervous system, heart, eyes, kidneys, lungs and bones [1][2]. The dermatological involvement is the most common manifestation of TSC. Hypochromic macules are frequent, specially before puberty, and may be the only manifestation of the disease in children. The neurological involvement causes exuberant symptoms, such as intellectual disability, autism spectrum disorder and epilepsy [3]. According to a number of reported patients, more than $90 \%$ had skin lesions, approximately $90 \%$ had symptoms of cerebral pathology, $70 \%-90 \%$ had renal abnormalities, and about 50\% had retinal hamartomas [4]. The classic triad of epilepsy, mental retardation and facial angliofibromatosis allowed the clinical diagnosis of TSC. In fact, the complete triad occurs in less than a third of all cases. Today, major and minor criteria for defining the disease are recognized [3][5]. In this article, the authors propose to report and discuss a case of tuberous sclerosis compared with literature data.

\section{Case Report}

ACSC male patient, 31-years-old, was referred by the Basic Health Unit to the Neurology outpatient clinic of the General Hospital of Nova Iguaçu due to difficultto-control epilepsy and severe intellectual disability. According to a family report, he had convulsions and a deficit in psychomotor development since childhood. Using phenobarbital 300mg/day regularly, he was unable to control his seizures. The mother denied a family history of a similar condition, and any complications during pregnancy and peripartum. The clinical examination showed a severe cognitive deficit, in addition to sebaceous adenomas like on the face, mainly in the nasal and malar regions (Figure 1). Carbamazepine was associated to control seizures and indicated brain magnetic resonance that showed "five focal areas of alteration in signal intensity characterized by iso / hyposignal in $\mathrm{T} 1$, hypersignal in T2 and FLAIR, compromising the corticosubcortical region of the frontal gyri, pre-central and medial temporal of the left cerebral hemisphere and of the medial and occipital temporal gyrus of the right cerebral hemisphere and another with a hypointense signal at $\mathrm{T} 1$, hyperintense at $\mathrm{T} 2$ and hypohyperintense at FLAIR, compromising the cortical-subcortical region of the left middle occipital gyrus; the lesions do not show contrast enhancement or diffusion restriction; the image aspect suggests the possibility of cortical tubers; tiny focus of hyposignal located on the topography of the ependymal surface of the lateral wall of the left lateral ventricle body that is difficult to characterize (calcified dubependymal nodule?) (Figure 2). He evolved with the seizures' control with serum dosage of drugs within the therapeutic range. Multidisciplinary monitoring started with a psychologist, physiotherapist, speech therapist, occupational therapy as well as family support and referral to the medical genetics service.

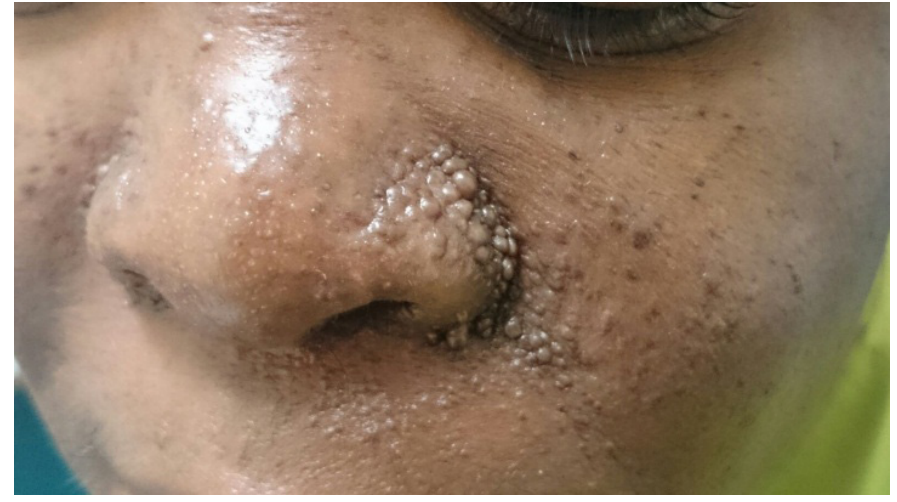

Figure 1: Facial angiofibroma image obtained with authorization from the person responsible for the patient.

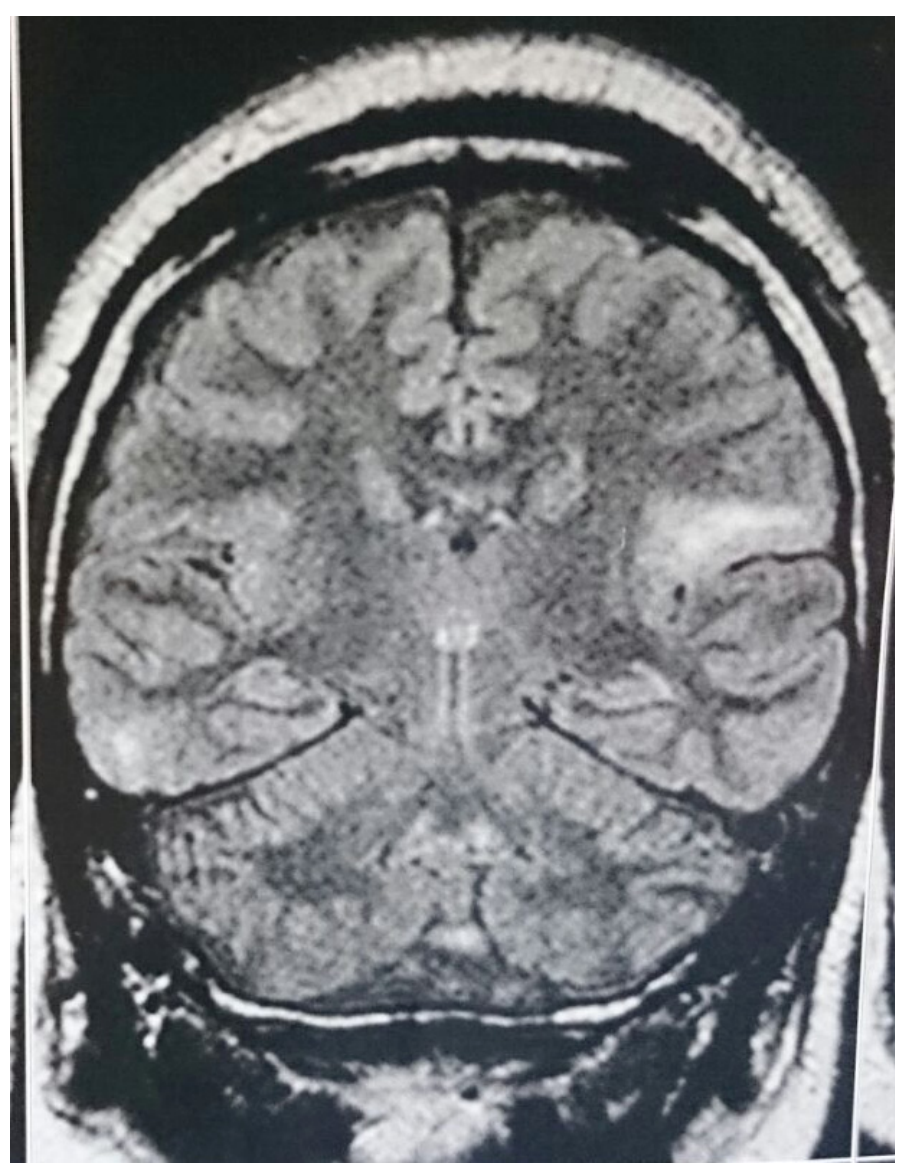

Figure 2: MRI showing an image suggestive of cortical tubers in the bilateral temporal cortical-subcortical region. 


\section{Discussion}

The neurocutaneous disorders or neuroectoderms comprise an extensive group of developmental disorders with involvement of the skin and central and/or peripheral nervous systems [6]. The term phakomatosis was originally used by Jan Van der Hoeve (ophthalmologist) to cover the three well-known neurocutaneous disorders at the time: Bourneville disease (tuberous sclerosis), von Recklinghausen disease (type 1 neurofibromatosis) and von Hippel-Lindau [6]. Recklinghausen was the first to describe patients with tuberous sclerosis complex (TSC), but the commonly applied eponym is "Bourneville" disease, after the French doctor studied and published the cases of several affected individuals [5]. TSC was originally defined by the Vogt clinical triad of sebaceous adenoma, epilepsy and mental disability. However, the modern definition of TSC does not require that all three elements of the classical triad to be present. Indeed, the complete triad occurs in less than a third of all cases [5]. The syndrome is an autosomal dominant disease with high penetrance and variability, characterized by the formation of benign lesions in various organ systems, mainly in the brain, kidney, retina, skin, heart and lung, the incidence is estimated at 1: 6000 [7]. More than two thirds of TSC cases are sporadic and the rest are familial cases. It is caused by more than 400 known DNA mutations involving the TSC1 gene located on chromosome 9934 encoding hamartin protein or the TSC2 gene located on chromosome 16p13.3, which encodes the tuberin protein. Both hamartin and tuberin interact to perform the tumor suppressor function [6]. Multisystemic hamartomas, are well-circumscribed groups of disorganized and dysplastic cells with a propensity to multiply excessively. They are benign tumors and may or may not cause symptoms [6].

Brain involvement is responsible for a significant proportion of the morbidity and mortality associated with the disorder, manifesting itself as epilepsy, developmental and behavioral problems, and the complications of tumor formation [8]. The most common findings in the brain of patients with TSC include tubers in the cortical parenchyma, which contribute to the high rate of epilepsy, but do not have a high rate of potential cancer growth. In magnetic resonance images, in most patients with TSC, subependymal nodules are found that line the ventricles, with a subset of nodules being completely or partially calcified, some with contrast enhancement. From 5\% to $20 \%$ of patients develop lesions of the nervous system known as subependymal giant cell astrocytomas (SEGAs), which arise from the subependymal nodules [9]. SEGAs are slow-growing tumors and usually have no symptoms until obstructive hydrocephalus develops, as they usually appear in the area adjacent to Monroe's foramen and due to their larger size, obstructive hydrocephalus is a feared complication [6].

Neurological changes vary from cognitively healthy patients who do not have epileptic seizures to ones that present severe cognitive impairment and treatmentrefractory epilepsy. Epilepsy is found in 75-90\% of patients, with infantile spasms, generalized tonic-clonic seizures and motor focal seizures standing out. $50 \%$ of patients have cognitive impairment and a good part of these patients have epilepsy [12].

The choice of antiepileptic varies from the type of syndrome and seizure presented by the patient, which makes it important to relate with dexterity in order to achieve pharmacological synergism, with less side effects. The surgical procedure is suggested as the therapy of choice for refractory epilepsy, even though the current therapy is covering two anticonvulsants [14]. Current research in animals has shown mTOR inhibitors as potential antiepileptic agents, attenuating spasms and enhancing autistic learning and attitudes, in addition, decreases the size of giant cell astrocytomas. The quality of life and morbidity and mortality are closely related to neurological manifestations, especially epilepsy and intellectual disability, emphasizing the importance of a multidisciplinary approach, with symptomatic and targeted therapy [13].

Classical skin changes in patients with TSC include multiple facial angiofibromas, preferably in the area of nasogenian grooves, zygomatic and mentum. Hypomelanotic macules in leaf form, cutaneous lesions in confetti, Shagreen plaques, periungual and lumbosacral fibroids complete the dermatological picture. Skin lesions usually appear between the age of five and puberty [10].

Renal lesions include hamartomas (angiomyolipomas) and hamartias (renal cysts). They are typically multiple, bilateral, generally innocuous and silent [11].

Eye injuries occur on the retina and optic nerve. They are described as astrocytomas (astrocytic hamartoma) and retinal hypo or hyperpigmentation. The incidence varies around $45 \%$ and, in half of the cases, they are bilateral, showing benign and stable behavior [1].

Lung involvement in TSC consists of a periarterial proliferation of smooth muscle in the interstitium of the lung parenchyma, predominantly in female patients. This leads to pulmonary hypertension and reorganization of the parenchyma in cystic spaces, which can rupture and produce pneumothorax [5].

Cardiac injury in TSC is rhabdomyoma. These are benign lesions that can affect the patient through ventricular obstruction [5]. Hamartomatous hemangiomas of the spleen and racemous angiomas of the liver are rare and generally asymptomatic [11].

The diagnosis of TSC is clinical, the diagnostic criteria are well established and divided into defined, probable, or possible TSC based on the combination of major or minor criteria, as described in Table 1 [2][6]. Even with a clinical diagnosis, the molecular study of TSC1 or TSC2 mutations is useful for confirming the diagnosis in individuals with possible or probable tuberous sclerosis criteria, but who do not meet the clinical criteria for the definitive diagnosis [2]. 


\begin{tabular}{|l|l|}
\hline TSC Diagnotic Criteria & $\begin{array}{l}\text { Definitive: } 2 \text { major or } 1 \text { major and } 2 \text { minor } \\
\text { Likely: 1 higher and 1 lower } \\
\text { Possible: } 1 \text { higher or } \geq 2 \text { smaller }\end{array}$ \\
\hline Major Criteria & $\begin{array}{l}\text { Facial angiofibromas or fibrous plaque } \\
\text { Non-traumatic periungual fibroma } \\
\text { Hypomelanocytic macules }(\geq 3) \\
\text { Shagreen Plates } \\
\text { Multiple nodular hamartomas of the retina } \\
\text { Cortical tubers } \\
\text { Subependymal nodule } \\
\text { Giant cell subependymal astrocytomas } \\
\text { Cardiac rhabdomyoma } \\
\text { Pulmonary lymphangiomyomatosis } \\
\text { Renal angiomyolipomas }\end{array}$ \\
& $\begin{array}{l}\text { Multiple stains on tooth enamel } \\
\text { Radial migration lines in white matter in } \mathrm{MRI} \\
\text { Bone cysts } \\
\text { Rectal hamartomatous polyps } \\
\text { Gingival fibroids } \\
\text { Non-renal hamartoma (liver, spleen and other } \\
\text { organs) } \\
\text { Achromic spot on the retina } \\
\text { Confetti-like skin lesions } \\
\text { Multiple kidney cysts }\end{array}$ \\
\hline
\end{tabular}

Table 1: Diagnostic Criteria in Tuberous Sclerosis Complex [2][6].

\section{Conclusion}

The Tuberous Sclerosis Complex is a multisystem pathology, with nonspecific clinical manifestations, which in many cases can delay the diagnosis. In the present clinical case, the patient had no family history of TSC and there is no consanguinity between the parents, which probably characterizes a new mutation. The mother also reported that the patient has had epileptic seizures since childhood. The ACSC patient has the clinical triad of Vogt, as well as having a definitive criterion for TSC because it presents three of the major criteria for diagnosing TSC (namely: facial angiofibromas, cortical tubules and subependymal nodules).

\section{References}

1. Borrelli BL et al. Tuberous sclerosis: case report. Rev. Ciênc. Méd., Campinas, 10(3): 100-103, set/ dez,2001.

2. Santalha M, Carrilho I, Temudo T. Tuberous sclerosis: diagnosis, follow-up and treatment. Acta Pediatr Port 2013;44(2):82-9.

3. Carbonera LA, Lajús JAS, Rodrigues CFA. Tuberous sclerosis - case report. Rev neurocienc 2013;21(3):392-395.

4. Rabito MJ, Kaye AD. Tuberous Sclerosis Complex: Perioperative Considerations. The Ochsner Journal. 2014;14(2):229-239.

5. Smirniotopoulos JG, Murphy FM. The phakomatoses. AJNR 13:725-746, Mar/ Apr 1992 0 195-6 108/ 92/ 1302-0725.

6. Nandigam K, Mechtler LL, Smirniotopoulos JG. Neuroimaging of neurocutaneous diseases. Neurol Clin 32 (2014) 159-192. 
7. Roth J et al. Subependymal Giant Cell Astrocytoma: Diagnosis, Screening, and Treatment. Recommendations From the International Tuberous Sclerosis Complex Consensus Conference 2012. Pediatric Neurology 49 (2013) 439-444.

8. Griffiths PD, Hoggard N. Distribution and conspicuity of intracranial abnormalities on MR imaging in adults with tuberous sclerosis complex: a comparison of sequences including ultrafast T2weighted images. Epilepsia, 50(12):26052610,2009 .

9. Campen CJ, Porter BE. Subependymal giant cell astrocytoma (SEGA) treatment Update. Curr Treat Options Neurol. 2011 August; 13(4): 380385. doi:10.1007/s11940-011-0123-z.

10. Perez EG, Paranaíba LR, Bonan PR, Orsi Júnior JM, de Oliveira AM, Martelli Júnior H. Tuberous sclerosis: evaluation of myofibroblasts in cutaneous angiofibromas - Case report. An Bras Dermatol. 2010;85(1):84-8.

11. Merrit, Neurology. Edited by Lewis P. Rowland. Rio de Janeiro: Guanabara Koogan, 2007.

12. Roach ES, Sparagana SP. Diagnosis of Tuberous Sclerosis Complex. J Child Neurol. 2004; (19):6439.

13. Wataya-Kaneda $M$, Tanaka $M$, Nakamura A, Matsumoto S, Katayama I. A novel application of topical rapamycin formulation, an inhibitor of mTOR, for patients with hypomelanotic macules in tuberous sclerosis complex. Arch Dermatol 2012;148(1):138-9.

14. Curatolo P, Jóźwiak S, Nabbout R. TSC Consensus Meeting for SEGA and Epilepsy Management. Management of epilepsy associated with tuberous sclerosis complex (TSC): Clinical recommendations. Eur J Paediatr Neurol 2012;16(6):1-5. 